\title{
The Effect of Strategic Orientation on Organizational Performance: The Mediating Role of Innovation
}

\author{
Bader Yousef Obeidat \\ Department of Business Management, Faculty of Business, The University of Jordan, Amman, Jordan \\ Email: b.obeidat@ju.edu.jo
}

How to cite this paper: Obeidat, B.Y. (2016) The Effect of Strategic Orientation on Organizational Performance: The Mediating Role of Innovation. Int. J. Communications, Network and System Sciences, 9, 478-505.

http://dx.doi.org/10.4236/ijcns.2016.911039

Received: September 15, 2016

Accepted: November 11, 2016

Published: November 14, 2016

Copyright $\odot 2016$ by author and Scientific Research Publishing Inc. This work is licensed under the Creative Commons Attribution International License (CC BY 4.0).

http://creativecommons.org/licenses/by/4.0/

\begin{abstract}
Survival in today's dynamic environment requires organizations to have superior performance compared to competitors. In order to achieve this superior performance, this study aimed to examine the effect of both strategic orientation and innovation on organizational performance. It also examined whether innovation acted as a mediator between strategic orientation and organizational performance. Data were gathered from the three telecommunication companies that exist in Jordan. The data were then analysed using Structural Equation Modelling (SEM) and the results revealed that strategic orientation had a significant effect on innovation but not on organizational performance. It was also found that innovation significantly affected organizational performance. Finally, the results indicated that innovation mediated the path between strategic orientation and organizational performance, but only partially.
\end{abstract}

\section{Keywords}

ATM, Security, Biometrics, PIN, Fingerprints, Iris

\section{Introduction}

Companies, institutions, and people in most sectors are facing intense competition which makes it extremely difficult for them to compete with their rivals and outperform them. In order to perform better than rivals, firms should gain competitive advantage [1] [2] [3]. Different techniques can be used to achieve such competitive advantage and superior performance [4] [5] [6]. Organizations strive to improve performance by developing and implementing effective business strategies that exploit opportunities in the marketplace while capitalizing on available resources and capabili- 
ties [7] [8] [9] [10]. A firm's strategy can have a major impact on its structure, its activities, its investment, its relation to the market, and its business performance. Strategy can be utilized as a problem solving tool that at the same creates new capabilities and improves performance [11]. A strategy can also provide a framework that allows an organization and its managers to assemble specialized assets, to identify opportunities for providing valued products and services to customers, and to deliver those products and services for higher profits in the marketplace [12]. However, not all firms respond to changes in the environment in the same way. The responses to the operating environment can be categorised according to the strategic orientation of the organization [13]. Even though the literature has emphasized the benefits associated with adopting a market orientation, it has been reported that firms need to pursue complementary strategic orientations since market orientation lone may not be comprehensive enough for achieving a competitive advantage [10].

Apart from exercising strategic orientation, firms are also encouraged to ensure alignment of different sets of organizational capabilities in order to pursue continuous innovation for sustainable success [14] [15]. Innovation is considered the best way to go in order to compete in the twenty first century as it fuels organizational growth, drives future success, and is the engine that allows organizations to sustain their viability [16]. The various challenges faced by organizations have forced them to embrace innovation as an integral part of corporate strategy [17]. Such challenges include global availability of knowledge, technology fusion, and shorter innovation cycles [18] [19]. Both incremental and radical innovations are considered major determinants of an organization's dynamic capabilities which influence its competitive advantage. Therefore, increasing the efficiency of radical and incremental innovations is considered one of the main concerns for practitioners [20]. Stagnant organizations that are unable to innovate to keep up with changing environments will eventually find themselves without a competitive advantage in an increasingly complex and technologically sophisticated economy [21] [22]. Therefore, innovation is well documented as an important driver of competitiveness, profitability and, productivity [13].

\section{Strategic Orientation}

One of the most important pillars that has major implications for an organization's structure, activities, investments, relations with the market, and performance is strategy [23]. Having a strategy helps organizations find solutions to problems, create new capabilities, and improve business performance [11] by allowing organizations and the managers to gather specific resources, recognise opportunities for providing valued products and services, and to convey those products and services for higher profits [12]. Adopting the best strategy out there requires organizations to coordinate their approaches in establishing industry positions and/or by relying on its resources, competences, and capabilities in an effort to achieve a fit with their internal and external environments and in turn achieve a sustained competitive advantage and improved business efficiency. In order to achieve these goals, organizations need to focus on their 
strategic orientation since strategic orientation guides the direction that a firm intends to pursue in order to monitor its activities for better business performance [24]. Therefore, strategic orientation of the firm reflects its operational, marketing, and entrepreneurial posture. By doing so, a firm achieves its goals in markets by taking risks, investing in innovation, becoming proactive, and developing future-oriented foresight [25].

Strategic orientation has received wide spread attention from management, marketing, and entrepreneurship scholars. However, no universally accepted definition of strategic orientation exists. The very nature of orientation is a matter of debate, and different streams of literature have developed diverse concepts. Orientation refers to the general or lasting direction of thought, inclination, or interest [26]. Strategic orientation refers to the manner in which a firm adapts to its external environment [27]. In other words it refers to the pattern of responses that an organization makes to its operating environment in an effort to enhance performance and gain competitive advantage [25]. Other scholars see strategic orientation as an aspect of organizational culture. Organizational culture is a form of intangible resources and the deployment of those resources, i.e. orientations, will have different impacts on the organization. Strategic orientation focuses resources to achieve desired outcomes [28]. This is supported by [29] who stated that strategic orientation manifests in the firm's culture and serves as antecedents to organizational practices and decisions associated with resources allocation and pursuing opportunities. In this paper, strategic orientation is viewed as principles that direct and influence the activities of a firm and generate the behaviours intended to ensure the viability and performance of the firm. These principles can also be used to guide the activities of the organization [30] [31] [32].

Previous studies have specifically advocated the use of behaviours associated with the organization wide generation, dissemination, and use of market intelligence as being the key ingredients of strategic orientation [33] [34]. A growing stream of studies today endorse the adoption of different strategic orientations such as innovation orientation, technology orientation, entrepreneurial orientation, quality orientation, and productivity orientation [35] [36]. For the purpose of this study, three types of strategic orientation will be looked into further: market orientation, entrepreneurial orientation, and technology orientation.

\subsection{Market Orientation}

Market orientation is regarded as a crucial strategy or capability that helps organizations stay competitive in today's uncertain business environment [37]. Market orientation is considered both a marketing concept and a management strategy [38]. According to various scholars, practitioners, and researchers, market orientation assists in developing marketing knowledge, superior performance, and competitive advantage [39] [40].

Various definitions have been suggested for market orientation by different scholars in the marketing literature [7]. [41] defined market orientation as a managerial deci- 
sion-making practice with a commitment shared within the organization. [33] referred to market orientation as the organization-wide generation of market intelligence pertaining to current and future customer needs, dissemination of the intelligence across departments, and organization wide responsiveness. [34] explained market orientation as composed of three dimension: customer orientation, competitor orientation, and inter-functional coordination.

According to this market orientation requires firms to monitor changing customer needs, determine the impact of those changes on customer satisfaction, increase the rate of product innovation, and implement strategies that build the firm's competitive advantage [42] [43]. The definition provided by [34] is adopted in this study, where customer orientation, competitor orientation, and inter-functional coordination reflect market orientation. Customer orientation refers to finding information about customers' needs and wants for the present and future in order to provide them with superior value added offerings [7]. Competitor orientation refers to considering the short-range fortes and flows, and long range abilities and tactics of existing and possible rivals to develop awareness of their information and strategies [7]. Inter-functional coordination enables firms to pick up warning or opportunity signals, process and convert them into specific departmental deliverables, and ensures convergence of efforts [29].

\subsection{Entrepreneurial Orientation}

Entrepreneurial orientation as a strategic orientation is concerned with the entrepreneurial aspects of a firm's strategy [30]. It determines a firm's willingness to stay ahead of its competitors and to take advantage of new opportunities to engage in innovation in an uncertain environment [44]. Entrepreneurial orientation is defined as an organization's willingness to find and accept new opportunities and implementing change as a result [3]. It also refers to the way organizations capture specific entrepreneurial aspects of decision making styles, methods, and practices [45]. In other words, entrepreneurial orientation relates to the methods, practices, and decision making styles that managers use to act entrepreneurially [46].

The entrepreneurial orientation concept suggests that firms should be entrepreneurial in order to achieve superior performance [47]. This means that organizations need to have a strategic commitment to specific, observable actions in the form of innovation, proactiveness, and risk taking, and the strong support of those actions by top management [48]. According to [49] [50] [51], engaging in product-market innovation, being the first to enter new markets, and understanding risky ventures are at the heart of entrepreneurship. Therefore, innovativeness, risk-taking, and proactiveness are used to represent entrepreneurial orientation in this study. Innovativeness refers to "the willingness to support creativity and experimentation in introducing new products/ services, and novelty, technological leadership and R\&D in developing new processes" ([52], p. 142). Proactiveness refers to seeking new opportunities in the market, anticipating future demands and opportunities in the market, participating in emerging markets, shaping the environment, and introducing new products and brands before 
their rivals [3]. Risk-taking refers to willingness to invest in large amounts of resources in projects whose results may be unknown and where the cost of failure may be high [53].

\subsection{Technology Orientation}

Technology is an important method for connecting customers and organizations. Organizations use technology to improve their ability to collect customer information [54] [55] [56] [57]. Furthermore, an organization that is guided by technology has the opportunity to accumulate vast technological knowledge stores by past experience and processes which might be used to its advantage [58]. A technology oriented firm seeks to acquire new and advanced technologies to develop new processes, products, and services, even though the rate of technological change within its industry might affect its technological adoption or development [12].

Technology orientation is defined as a firm's inclination to introduce or use new technologies, products, or innovations. It suggests that customer value and the longterm success of the organization depends on new innovations, technological solutions, products, services, or processes [30]. [59] stated that an organization's technical skills, $\mathrm{R} \& \mathrm{D}$ resources, and technological base can be central in bringing innovative, better designed products into the market. As a result, a technology oriented organization is proactive in acquiring new technology and applying the latest technologies to develop new products/services or supporting applications. Accordingly, it is proposed that a company's technology orientation should lead to the development of more innovative, technologically superior products compared to those offered by competitors [57]. Technology orientation thus contributes tremendously to the improvement of product performance and business performance [60].

To summarize, while market orientation is mainly focused on the external environment of the organization, in terms of its customers and competitors, and in turning market knowledge into valuable actions, technology orientation approaches the same customer value dilemma but from an internal perspective. The development of new technologies, products, and services are seen as key to creating customer value and providing organizations with a competitive advantage. Entrepreneurial orientation suggest that certain behaviours or processes-namely innovativeness, proactiveness, and risk-taking-are crucial for success [30].

\section{Innovation}

Innovation has been investigated for several years now and has been referred to as a black box [61]. Theoretically innovation has been reported to rest on the resourcebased of the firm [62]. This view suggests that managing and combining different types of resources leads to the development of dynamic capabilities. Based on this view in order to organize the innovation process efficiently, technological capabilities must be combined with various skills such as marketing, management, and organizational competencies [63] [64]. Another perspective is the knowledge-based view of the firm 
which builds upon and extends the resource-based view of the firm. Based on this perspective intangible resources are considered an organization's most important resource. This is because an organization's competitive advantage is not just the product of tangible resource as much as it is the product of the services rendered by those resources that are in turn a function of the firm's know how [65] [66] [67]. This perspective mainly focuses on learning in order to create new knowledge. However, the amount of information present is not the important thing, rather the application of that knowledge to create new knowledge [68]. Therefore, an organization's management is concerned with both organizational learning and innovation [69]. A recent evolution of the knowledge-based perspective recognizes that both tangible and intangible resources that are available to the organization and thus organization and thus are considered its main strategic tool.

[70] (p. 104) defined innovation as "a management process, involving multiple activities, performed by multiple actors, from one or several organizations during which new combinations of means and/or ends, which are new for a creating and/or adopting unit, are developed and/or produced and/or implemented, and/or transferred to old and/or new market partners". Innovation can also be defined as the adoption of an idea, behaviour, system, policy, program, device, process, product or service that is considered new to the organization [64]. A definition that is considered relevant to this study is the one provided by [71] (p. 5) which refers to innovation as "the process of making changes, large and small, radical and incremental, to products, processes, and services that results in the introduction of something new for the organization that adds value to customers, and contributes to the knowledge store of the organization".

Innovation research can be approached from several perspectives such as the individual, organization, and a nation. Organizational level innovation can be grouped from into four categories. The first one is connected with the type of innovation, including innovation typology [72], its comparisons, and illustrations of various types of innovation. Innovation types are classified based on the outcome of the innovation process. Some of these classifications include: organizational structure, production process, people, products/services, technical, administrative, incremental, and radical. [73] proposed the following innovation typology: product (including radical and incremental) and process (including administrative, service, and production). Some scholars identified three types of innovation: incremental, really new, and radical [74]. Others have suggested classifying innovation into administrative vs. technical based on the objective of innovation adoption, rational plans vs. communication web vs. disciplined problem solving based on innovation's effect on firm competence, ad radical vs. incremental based on the extent of change in technology [20]. Innovation can also be seen in terms of extremes such as radical and incremental, continuous and discontinuous, and sustainable and disruptive innovations [75].

The second category relates to the diffusion of innovation from various sources [76]. According to [77], the implementation of innovation depends on three factors: framing, innovation environment, and innovation attributes. Framing refers to the facilitat- 
ing of an innovation in terms of political and strategic imperatives of the organization. Innovation environment refers to the internal tactical environment for innovation implementation. Innovation attributes refer to the characteristics of the innovation. However, having only one of these factors on its own is not sufficient to ensure success; a combination of these factors must exist to ensure the successful implementation of an innovation.

The third category examines the antecedents or determinants of organizational innovation [78]. According to the literature two factors influence innovation which includes internal factors and external factors. Internal factors include the management and strategy of the firm, employees of the firm, and R\&D department. The two internal factors of management and strategy, and employees are considered as the most important for innovation [79]. This is because managers need to balance and lead the innovation process and make sure that the innovation fits the organization's strategy. Employees are important because they gain valuable knowledge from their interactions with customers thereby incorporating their knowledge in service innovation [80]. External factors include competition, deregulation, isomorphism, resource scarcity, and customer demand [81]. [79] suggested that external factors influencing innovation include trajectories which refer to the ideas and logic that are diffused through social systems, and actors which refer to key market actors such as customers, suppliers, and competitors. Customers, suppliers, law makers, and other authorities influence the environment of organizations and can directly and indirectly influence organizations to innovate. Therefore, organizations need to understand their environments and adapt to evolving conditions [61].

Customer expectation is perhaps the most important external factor as companies build their innovation based on local customers' expectations [82]. Internal factors are considered more important than external factors as [83] stated that innovation is highly dependent on internal factors rather than external factors.

The fourth category adopts a consequence or result approach in terms of the relationship between innovation and organizational performance [84]. Organizational performance is considered the ultimate aim of implementing innovation as innovation involves not only providing access to markets but also enhancing and maintaining performance [85]. In this study the first category will be investigated as innovation type is considered the main focus here. More specifically radical and incremental innovations will be used as dimensions to measure innovation based on the study conducted by [86].

\subsection{Incremental Innovation}

Incremental innovation is considered an important force behind any improvement effort as it leads to the accumulation of day-to-day improvements and thereby considered the backbone of organizational performance [16]. Incremental innovation refers to minor changes or made to products, services, and processes that result in little departure from existing practices [87]. In other words it results in slight variations or improvements of existing products, services, practices, and approaches [20]. These im- 
provements include changes made to the materials used to make a product or improve service operations [21]. According to [88], in some organizations incremental innovation does not make existing products obsolete, it just improves existing technological trajectories. In other organizations incremental innovation is considered a means to improve performance. Furthermore, incremental innovation is used by firms competing in what is referred to as "red oceans" or existing markets that operate in industries with clear boundaries and known rules of competing [89].

Incremental innovation also tries to meet the needs of customers or markets at a rate consistent with current technological trajectory [90]. This is done by having a strategy that focuses on market dominated growth with diversification by improving and expanding current products and services within a short period of time [91]. Implementing incremental innovation requires technical, market, and financial analysis prior to the development of the new product in addition to well defined product concept [74]. Incremental innovation also requires the ability to reinforce, recombine, and take advantage of existing knowledge resources [92].

Adopting an incremental innovation approach benefits organizations $\mathrm{n}$ terms of achieving and sustaining short-term financial performance [74], increasing efficiencies, sustaining technology and thinking with refinements over time [93], lowering costs, enhancing effectiveness [94], and lowering risks. However, the disadvantage of using incremental innovation is the slowness to reach targets before competitors which in turn leads to the loss of competitive advantage in comparison with radical innovation [71].

\subsection{Radical Innovation}

Surviving in today's business environment requires continually innovating by reinventing new products, processes, and business concept. Relying on incremental innovation is no longer a viable business strategy. In order to survive the volatility of the environment which includes the emergence of global markets, powerful technologies, and shortened product life cycles, firms need to be able to radically innovate and adapt quickly to changing conditions [93].

Radical innovation has several descriptions such as discontinuous innovation, emerging technology, and disruptive technology [75]. Radical innovation can be seen as an abrupt major change or doing something differently from what was done before [16]. [95] defined radical innovation as products and technologies that have a high impact on the market in terms of offering new benefits, improving known benefits, or reducing costs. [96] extended this definition stating that radical innovation refers to the products and technologies that have a strong impact on the market in terms of new benefits and on the firm in terms of creating new businesses. Further, radical innovation results in something new such as new products or processes and is associated with fundamental changes that are often implemented through specific innovation projects. All these definitions of radical innovation relate to aspects of high market and technological uncertainty, new market creation, new capabilities, and the possibility that such innovations might cannibalize a firm's prior business model [75]. 
Radical innovation can be seen from different perspectives. For customers radical innovation implies greater change their behaviour in order to take advantage of the benefits offered by radical innovation. For firms radical innovation requires major changes in the organization [97]. Furthermore radical innovation means different things to different organizations. For example in innovation generating organizations radical innovation means creating new technologies, products, or services that would drastically influence firm's competitiveness by making existing technology, products, or services obsolete. In innovation adopting organizations, radical innovation results in major changes in the organization and its strategy [88].

The general aim of innovation is to meet the need of emerging customers or markets. In order to so it follows a long term aggressive strategy where organizations attempt to disrupt prevailing technological trajectories and create new designs, technologies, and distribution channels for new markets. However, creating radically new products and services and successfully marketing them is considered very difficult [20]. This is because the product concept is undetermined in the initial stages of the innovation process and input from customers very early in the process is considered unhelpful as customers have nothing to compare the new concept with or are unable to visualize the potential use of a radically new product [74]. Therefore, the success of radical innovation depends on several factors such as extending customer and competitor research beyond traditional boundaries to learn from other industries [93], the ability to make existing technologies obsolete by transforming old knowledge into new knowledge, and building on knowledge resources that the firm does not have yet or is different from existing ones [20].

Radical innovation yields several benefits such as creating step change in growth, increased sales, extraordinary profits [71], Competitive advantage [74]. However, there are some disadvantages to adopting radical innovation. For example, radical innovation is considered highly resource intensive. It also involves a high level of risk and high cost of failure [71]. Radical innovation is considered more risky than incremental innovation because it requires substantial investments in new technologies or markets in addition to uncertain outcomes [74]. Furthermore, high degrees of risk and failure rates associated with radical innovation are the result of long-term development of radical innovation [88] where [98] stated that the time it takes for a concept to reach macrocommercialization through radical innovation is over 20 years on average.

Even though there has been great debate regarding which innovation type is more important, managers have realized the necessity for both radical and incremental innovations [16]. According to [71], organizations usually have a portfolio of innovations rather than just one specific innovation. Here many incremental innovations are undertaken to yield short term results. They may also develop radical innovations that lead to significant results in the medium and long term. Therefore, it can be noticed that both radical and incremental innovations go hand in hand as incremental innovation would reach its limit without radical innovation and without incremental innovation the potential created by radical innovation would not be captured [94]. 


\section{Organizational Performance}

Improving organizational performance is considered an essential requirement for corporate strategic management, and as a result organizations tend to invest most of their efforts to improve their performance [99] [100]. The potential success of an organization depends to a large degree on its performance, which relates to its ability to effectively implement strategies to achieve organizational objectives [101].

Several researchers have provided different definitions for organizational performance, since organizational performance is a fairly broad concept, and its meaning changes in accordance with the user's perspective and needs [27] [102]. Organizational performance reflects the way an organization takes advantage of tangible and intangible resources to achieve its goals [103] and the culmination of an organization's working process and activities [104]. [105] defined organizational performance in relation to the organization's goals and objectives. [106] referred to organizational performance as the actual results or outputs of an organization as measured against that organization's intended outputs. Since organizational performance is a multidimensional concept, it seeks to measure companies' achievement of the objectives proposed for different stakeholders in a given period [107].

Traditionally, the term performance was associated with measurements such as profit, costs, and market share. However, it has been suggested that performance should not be treated solely as a financial concept. Managers nowadays tend to place relatively less emphasis on traditional financial measures in favour of approaches that shift focus away from strict accounting consideration to more generic issues of business performance [27]. Different organizations use various types of measurement to evaluate performance, the most commonly used today includes financial and non-financial performance indicators [7].

Financial performance relates to data present in financial statements and accompanied notes [108] such as profitability, sales growth, return on sales, return on investment, and return on equity [3]. Nonetheless, [109] claimed that financial measures of performance only capture one part of organizational performance. This is supported by [110] who advocated the movement toward recognizing non-financial measures, given that they focus on a firm's long-term success [27]. Non-financial performance relates to the organization's effective marketing activities and can be evaluated through customer loyalty, customer satisfaction, market share, quality, new product development, and so on [3] and [111]. These measures offer an alternative perspective on performance and are key behaviours for supporting the achievement of positive financial performance [112]. In this study non-financial performance was relied on to represent organizational performance.

\section{Research Methodology}

\subsection{Research Model and Hypotheses}

Based on the previous literature, the major elements of this research are established either theoretically or empirically. Figure 1 represents a model for the study that shows 


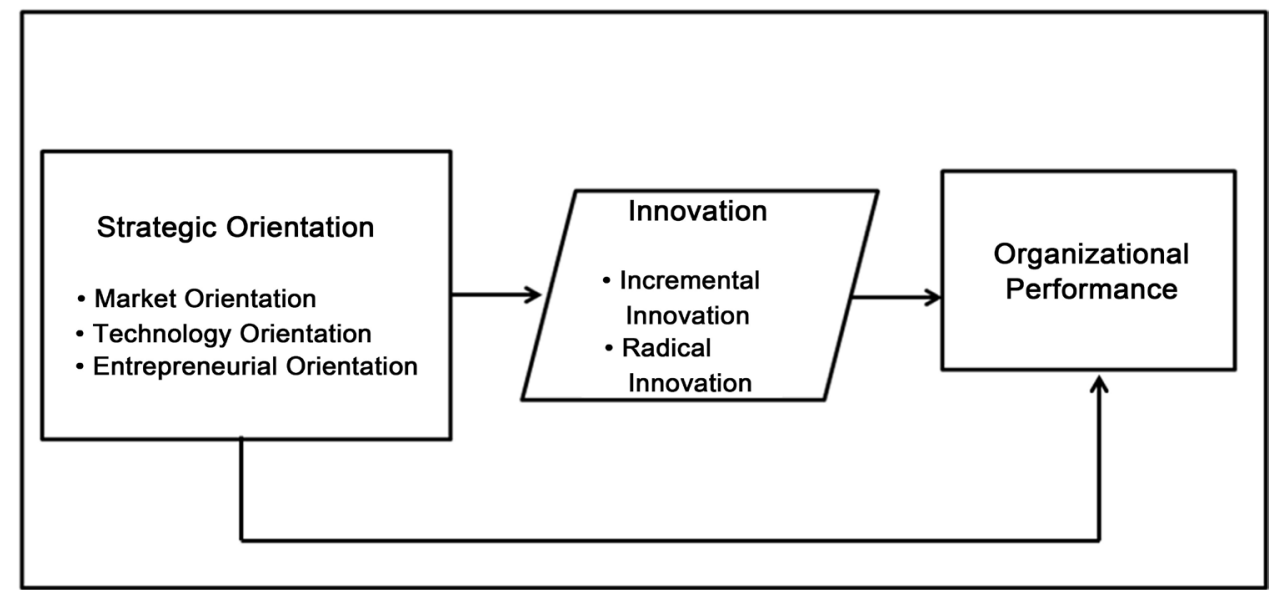

Figure 1. Research model.

the independent variables within the construct of strategic orientation, the mediating variable (innovation), and the dependent variable (organizational performance), and the proposed relationship between them.

In order to test the relationship between the proposed variables, the following null hypotheses were developed.

$\mathrm{H}_{1}$ : Strategic orientation significantly affects organizational performance.

$\mathrm{H}_{2}$ : Strategic orientation significantly affects innovation.

$\mathrm{H}_{3}$ : Innovation significantly affects organizational performance.

$\mathrm{H}_{4}$ : Innovation has a mediating effect on the strategic orientation-organizational performance linkage.

\subsection{Research Design}

This research uses structural equation modelling (SEM) in order to study the relationships proposed by the research model and to test the hypotheses. The basis for data collection and analysis is a field study in which respondents answered all items on a five point Likert-scale ranging from 1 (strongly disagree) to 5 (strongly agree). Prior research was the basis from which elements were extracted to represent the different constructs of this study. These elements provided a valued source for data gathering and measurement as their reliability and validity have been verified through previous research and peer reviews.

Strategic orientation and its corresponding items (i.e. market orientation, technology orientation, and entrepreneurial orientation) were adapted from [113]. Innovation construct and its corresponding items (i.e. incremental innovation and radical innovation) were derived from [86]. Organizational performance, represented by non-financial performance, was adapted from [114].

\subsection{Sample and Procedure}

A self-administered questionnaire was used to gather data for hypotheses testing from employees working in telecommunication companies, which include Zain, Orange, and 
Umniah. The instrument was reviewed by 10 employees at different from the three different companies in order to identify problems with wording, content, and question ambiguity. Some minor edits were introduced and some changes were made based on their suggestions. The sample size of this study was determined based on the Morgan table where (252) employees were considered an appropriate sample size for statistical analysis [115]. The demographic data of the respondents are reported in Table 1.

The majority of the participants in this study were males with a percentage of (51.6\%), whereas the female participants represented (48.4\%) of the total participants. With regards to age, it can be concluded that the employees working in telecommunication companies are aged between 25 and less than 30 years old with a percentage of (36.1\%). The remaining employees are categorized as follows: $26.6 \%$ less than 25 years old, $22.6 \%$ from 30 - less than 35, and $14.7 \%$ are 35 years old and above. These results may be explained by the fact that telecommunication companies require the presence of constant creativity, innovation and the use of new technology on the part of its employees, which can be found in the younger generation compared to older generations.

In terms of experience, it can be noted that most of the employees have an experience of 3-less than 6 years as indicated by the percentage (35.3\%). 31.7\% of respondents have an experience of less than 3 years, $21.4 \%$. Regarding position, the majority of the respondents were employees with a percentage of (65.1\%). The other respondents were

Table 1. Demographic data for respondents.

\begin{tabular}{|c|c|c|}
\hline Category & Frequency & Percentage $\%$ \\
\hline \multicolumn{3}{|l|}{ Gender } \\
\hline Male & 130 & 51.6 \\
\hline Female & 122 & 48.4 \\
\hline \multicolumn{3}{|l|}{ Age } \\
\hline Less than 25 years & 97 & 26.6 \\
\hline From 25 - less than 30 years & 91 & 36.1 \\
\hline From 30 - less than 35 years & 57 & 22.6 \\
\hline 35 years and over & 37 & 14.7 \\
\hline \multicolumn{3}{|l|}{ Experience } \\
\hline Less than 3 years & 80 & 31.8 \\
\hline From 3 - less than 6 years & 89 & 35.3 \\
\hline From 6 - less than 9 years & 29 & 11.5 \\
\hline 9 years and over & 54 & 21.4 \\
\hline \multicolumn{3}{|l|}{ Position } \\
\hline Top management level & 22 & 8.7 \\
\hline Middle management level & 26 & 10.3 \\
\hline Supervisory level & 40 & 15.9 \\
\hline Employee & 164 & 65.1 \\
\hline
\end{tabular}


categorized as follows: $15.9 \%$ supervisors, $10.3 \%$ holding a position in middle management, and $8.7 \%$ holding a position in top management. These results reveal that the work of the company is mostly performed by lower level employees who can be referred to as the engine that runs the company.

\section{Research Results}

\subsection{Descriptive Statistics}

In order to describe the responses and thus the attitude of the respondents toward each question they were asked in the survey, the mean and the standard deviation were estimated. While the mean shows the central tendency of the data, the standard deviation measures the dispersion which offers an index of the spread or variability in the data [115] [116]. In other words, a small standard deviation for a set of values reveals that these values are clustered closely about the mean or located close to it; a large standard deviation indicates the opposite. The level of each item was determined by the following formula: (highest point in Likert scale - lowest point in Likert scale)/the number of the levels used $=(5-1) / 5=0.80$, where $1-1.80$ reflected by "very low", $1.81-2.60$ reflected by "low", 2.61 - 3.40 reflected by "moderate", 3.41 - 4.20 reflected by "high", and 4.21 - 5 reflected by "very high". Then the items were being ordered based on their means. Table 2 shows the results.

As presented in Table 3, data analysis results have shown that strategic orientation and innovation do exist highly and respectively. Also, organizational performance is applied to a greater extent.

\subsection{Measurement Model}

Confirmatory factor analysis (CFA) was conducted to check the properties of the

Table 2. Overall mean and standard deviation of the study's variables.

\begin{tabular}{cccccc}
\hline Type of variable & Variables & Mean & Standard deviation & Level & Order \\
\hline Independent variables & Strategic orientation & 3.72 & 0.28 & High & \\
& Market orientation & 3.90 & 0.37 & High & 1 \\
& Technology orientation & 3.83 & 0.50 & High & 2 \\
& Entrepreneurial orientation & 3.43 & 0.56 & High & 3 \\
Mediating variable & Innovation & 3.73 & 0.70 & High & \\
& Incremental innovation & 3.80 & 1.03 & High & 1 \\
& Radical innovation & 3.66 & 0.92 & High & 2 \\
Dependent variable & Organizational performance & 3.95 & 0.40 & High & \\
\hline
\end{tabular}

Table 3. Measurement model fit indices.

\begin{tabular}{ccccccccccc}
\hline Model & $\mathbf{x}^{2}$ & Df & $\mathbf{P}$ & $\mathbf{x}^{2} / \mathbf{d f}$ & IFI & TLI & CFI & GFI & AGFI & RMSEA \\
\hline Initial model & 2989.467 & 1259 & 0.000 & 2.374 & 0.76 & 0.75 & 0.74 & 0.78 & 0.81 & 0.074 \\
Final model & 1768.682 & 725 & 0.000 & 2.440 & 0.85 & 0.85 & 0.84 & 0.86 & 0.90 & 0.065 \\
\hline
\end{tabular}


instrument items. Indeed, the measurement model indicates how latent variables or hypothetical constructs are assessed in terms of observed variables; and embodies the validity and reliability of the observed variables responses for the latent variables [117] [118].

Table 3 shows different types of goodness of fit indices in assessing this study initial specified model. Because the initial CFA model did not provide an acceptable fit, twelve items (MO5, MO6, MO7, MO8, TY8, TY9, TY10, EO5, EO6, NF7, NF8, and NF9) were eliminated to obtain a better fitting measurement model. The results of the revised CFA indicated that the chi-square $\left(\mathrm{x}^{2}\right)$ value of the model was 1768.682 , with 725 degrees of freedom $(\mathrm{p}<0.05)$, which implies that the measurement did fit the data well. The other model fit indices used for this study were the $\mathrm{x}^{2} / \mathrm{df}(1768.682 / 725=2.440$; threshold less 3 for a serious viewpoint or less 5 for acceptable criteria), the Incremental Fit Index (IFI) of 0.85, Tucker-Lewis Index (TLI) of 0.85, Comparative Fit Index (CFI) of 0.84, the Goodness-of-Fit Index (GFI) of 0.86, the Adjusted Goodness-of-Fit Index (AGFI) of 0.90, and the Root Mean Square Error of Approximation (RMSEA) of 0.065. Based on these fit indices, the measurement model appeared to fit the sample data well [118].

Table 4 shows the factor loadings, Cronbach alpha, composite reliability, and Average Variance Extracted (AVE) for the variables. All of the indicators of the factor loadings exceeded 0.50, thus constitute evidence of convergent validity [117] [119]. Indeed, while the measurement reached convergent validity at the item level because all of the factor loadings went above 0.50 except twelve items (MO5, MO6, MO7, MO8, TY8, TY9, TY10, EO5, EO6, NF7, NF8, and NF9), all of the composite reliability values exceeded 0.60 , demonstrating a high level of internal consistency for the latent variables. In addition, since each value of AVE exceeded 0.50 [117] [118]; the convergent validity was proved.

\subsection{Structural Model}

The SEM analysis revealed that strategic orientation directly, positively, and significantly affected innovation $(\beta=0.263, t=2.132, \mathrm{p}=0.033)$; thus, $\mathrm{H}_{2}$ was accepted. Also, innovation found to be directly and positively impacted organizational performance; consequently, $\mathrm{H}_{3}$ was accepted (see Table 5). However, $\mathrm{H}_{1}$ was rejected as $(\beta=0.081, \mathrm{t}$ $=1.320, \mathrm{p}=0.182)$; that strategic orientation did not impact organizational performance. Furthermore, the coefficient of determination $\left(\mathrm{R}^{2}\right)$ for the research endogenous variables for innovation, and organizational performance were 0.36 , and 0.23 respectively, which indicates that the model does account for the variation of the proposed model.

To test the mediating effects of IN, the study looked at both the direct effect of SO on OP and its indirect effect through the mediatory path of IN. It was found that SO affects OP significantly both directly $(\alpha=0.210)$ and indirectly $(\alpha=0.223)$, resulting in a total effect size of $\alpha=0.433$ (see Table 6). Thus, the data supported partial mediation.

\section{Discussion}

This paper explored the mediating role of innovation in the relationship between 
Table 4. Properties of the final measurement model.

\begin{tabular}{|c|c|c|c|c|c|c|c|}
\hline $\begin{array}{l}\text { Constructs and } \\
\text { indicators }\end{array}$ & $\begin{array}{c}\text { Factor } \\
\text { loadings }\end{array}$ & $\begin{array}{l}\text { Std. } \\
\text { error }\end{array}$ & $\begin{array}{c}\text { Square } \\
\text { multiple } \\
\text { correlation }\end{array}$ & $\begin{array}{c}\text { Error } \\
\text { variance }\end{array}$ & $\begin{array}{c}\text { Cronbach } \\
\text { alpha }\end{array}$ & $\begin{array}{l}\text { Composite } \\
\text { reliability* }\end{array}$ & $\mathrm{AVE}^{* *}$ \\
\hline $\begin{array}{c}\text { Market } \\
\text { orientation }\end{array}$ & & & & & 0.717 & 0.94 & 0.61 \\
\hline MO1 & 0.565 & $* * *$ & 0.322 & 0.321 & & & \\
\hline MO2 & 0.737 & 0.109 & 0.235 & 0.332 & & & \\
\hline MO3 & 0.855 & 0.101 & 0.432 & 0.311 & & & \\
\hline MO4 & 0.789 & 0.089 & 0.532 & 0.312 & & & \\
\hline MO9 & 0.535 & 0.081 & 0.435 & 0.335 & & & \\
\hline MO10 & 0.616 & 0.085 & 0.541 & 0.341 & & & \\
\hline MO11 & 0.733 & 0.065 & 0.245 & 0.336 & & & \\
\hline MO12 & 0.843 & 0.053 & 0.347 & 0.321 & & & \\
\hline MO13 & 0.719 & 0.078 & 0.632 & 0.319 & & & \\
\hline MO14 & 0.664 & 0.093 & 0.625 & 0.338 & & & \\
\hline MO15 & 0.871 & 0.092 & 0.529 & 0.346 & & & \\
\hline $\begin{array}{l}\text { Technology } \\
\text { orientation }\end{array}$ & & & & & 0.792 & 0.93 & 0.65 \\
\hline TO1 & 0.641 & $* * *$ & 0.341 & 0.216 & & & \\
\hline TO2 & 0.587 & 0.123 & 0.365 & 0.214 & & & \\
\hline TO3 & 0.740 & 0.098 & 0.265 & 0.344 & & & \\
\hline TO4 & 0.659 & 0.078 & 0.412 & 0.344 & & & \\
\hline TO5 & 0.633 & 0.056 & 0.312 & 0.144 & & & \\
\hline TO6 & 0.758 & 0.079 & 0.431 & 0.144 & & & \\
\hline TO7 & 0.520 & 0.098 & 0.439 & 0.144 & & & \\
\hline $\begin{array}{c}\text { Entrepreneurial } \\
\text { orientation }\end{array}$ & & & & & 0.785 & 0.93 & 0.68 \\
\hline EO1 & 0.803 & $* * *$ & 0.278 & 0.251 & & & \\
\hline $\mathrm{EO} 2$ & 0.830 & 0.083 & 0.298 & 0.263 & & & \\
\hline EO3 & 0.650 & 0.092 & 0.431 & 0.265 & & & \\
\hline EO4 & 0.651 & 0.089 & 0.468 & 0.231 & & & \\
\hline EO7 & 0.756 & 0.094 & 0.437 & 0.321 & & & \\
\hline EO8 & 0.891 & 0.093 & 0.340 & 0.333 & & & \\
\hline EO9 & 0.646 & 0.091 & 0.357 & 0.219 & & & \\
\hline $\begin{array}{l}\text { Incremental } \\
\text { innovation }\end{array}$ & & & & & 0.909 & 0.86 & 0.68 \\
\hline II1 & 0.849 & $* * *$ & 0.445 & 0.421 & & & \\
\hline
\end{tabular}




\section{Continued}

\begin{tabular}{ccccccc}
\hline II2 & 0.879 & 0.097 & 0.347 & 0.329 & & \\
II3 & 0.903 & 0.104 & 0.429 & 0.348 & & \\
Radical \\
innovation
\end{tabular}

${ }^{\star}$ Employing [120] formula, the composite reliability calculation is expressed by the following equation: Composite Reliability $=\left(\sum L i\right)^{2} /\left(\left(\sum L i\right)^{2}+\sum \operatorname{Var}(E i)\right)$ where $L i$ is the standardized factor loadings for each indicator, and $\operatorname{Var}(E i)$ is the error variance associated with the individual indicator variables. ${ }^{*}$ The formula for the variance extracted is: Average Variance Extracted $=\left(\sum L i\right)^{2} /\left(\left(\sum L i\right)^{2}+\sum \operatorname{Var}(E i)\right)$ where $L i$ is the standardized factor loadings for each indicator, and $\operatorname{Var}(E i)$ is the error variance associated with the individual indicator variables.

Table 5. Summary of proposed results for the theoretical model.

\begin{tabular}{ccccc}
\hline Research proposed paths & Coefficient value & t-value & p-value & Empirical evidence \\
\hline $\mathrm{H}_{1}: \mathrm{SO} \rightarrow \mathrm{OP}$ & 0.081 & 1.320 & 0.182 & Not supported \\
$\mathrm{H}_{2}: \mathrm{SO} \rightarrow \mathrm{IN}$ & 0.263 & 2.132 & 0.033 & Supported \\
$\mathrm{H}_{3}: \mathrm{IN} \rightarrow \mathrm{OP}$ & 0.255 & 1.987 & 0.047 & Supported \\
\hline
\end{tabular}

SO: Strategic Orientation; IN: Innovation; OP: Organizational Performance.

Table 6. Mediating effect of innovation.

\begin{tabular}{ccccccc}
\hline Hypothesis & From & Mediation & To & Direct effect & Indirect effect & Total effect \\
\hline $\mathrm{H}_{4}$ & SO & IN & OP & 0.210 & 0.223 & 0.433 \\
\hline
\end{tabular}

SO: Strategic Orientation; IN: Innovation; OP: Organizational Performance. 
strategic orientation and organizational performance in telecommunication companies in Jordan. The results were as follows.

$\mathrm{H}_{1}$ : Strategic orientation significantly affects organizational performance.

In this study it was found that strategic orientation did not affect organizational performance, which supports the findings of researchers such as [121] [122] [123]. Even though it is claimed that strategic orientation has appositive effect on organizational performance [4] [124] [125] [126] [127], the results of this study indicate otherwise. The reason behind this contradiction may be related to the fact that most of the previous studies mentioned relied upon a single measure of strategic orientation or measures different to the ones utilized in this paper. It may also be related to the use of financial measures to represent organizational performance in those studies, whereas this study focused on non-financial measures of organizational performance.

Furthermore, it has been reported that the effects of strategic orientation evolve overtime and that the implementation of strategy is what truly matters for improved organizational performance [4]. Therefore, it may be concluded that in the case of telecommunication companies in Jordan are not necessarily implementing their proposed strategies in the right way, thereby reducing the full impact that can be received from those strategies on their performance.

$\mathrm{H}_{2}$ : Strategic orientation significantly affects innovation.

In accordance with previous literature [17] [25] [28] [128] [129] [130], it was found that strategic orientation is an antecedent of innovation. As a result, it can be argued that this study theorized and empirically validated the idea that firms with high levels of strategic orientation are better able to include innovative strategic choices in their current and future operations. This conclusion may be attributed to the types of strategic orientation chosen in this study. For instance, market orientation has been reported to play a major role in the creation of a firm's innovative competence [131]. Specifically, market orientation positively affects the development of two certain competences; exploitation and exploration. Exploitation and exploration capabilities refer to existing resources that are transformed into new functional competences to better fit changing market conditions [132]. Therefore, when firms receive market insight they are bale to seize market opportunities in an effort to improve their current capabilities or to develop new capabilities [57].

Moreover, technology orientation can also lead to the development of innovative competences. According to [59], the technical skills, R\&D resources, and technological base possessed by a firm can be central to bringing about innovative, better designed products and services into the market. Such a technology-orientated firm is proactive in acquiring new technologies and applying the latest technology to develop new products or services or support its existing applications [57]. Consequently, a firm's technology orientation should lead to the development of more innovative, technologically superior products/services compared to competitors.

$\mathrm{H}_{3}$ : Innovation significantly affects organizational performance.

The importance of innovation as a driver of performance has been well covered in 
the literature [73] [133]-[138]. The results obtained in this study support this conclusion, where innovation was found to have a positive significant effect on organizational performance. The premise behind this is that innovation enhances the organization's flexibility, willingness to change, and the introduction of new products/services while reducing organizational inertia [42]. Therefore, it can be said that the adoption of innovation leads to ensured adaptive behaviour and organizational change that are key for maintaining or improving performance [81]. Moreover, innovation offers a way for organizations to breathe new life into existing products. This value added feature allows organizations to enter new markets and reach new customers, which has a tremendous impact on the performance of organizations [28].

$\mathrm{H}_{4}$ : Innovation has a mediating effect on the strategic orientation-organizational performance linkage.

Innovation was found to have a partial mediating effect on the relationship between strategic orientation and organizational performance. Other researchers have attempted to study the same path suggested in this study. [139] [140] found that innovation fully mediated the relationship between strategic orientation and organizational performance, whereas [141] reported a partial mediating effect consistent with this study. Innovation is considered a good variable for mediation since most types of strategic orientation (i.e. market, technology, and entrepreneurship orientations) have been proven to have positive relationships with innovation and performance, and innovation with performance as indicated in the previous sections of this study. Market orientation relates to implementing something new or different as a response to market conditions and may be perceived as innovative behaviour. Such market oriented firms are able to enhance the level of innovation and enjoy greater levels of success in the market [42].

Although both market orientation and innovation have significant effects on performance, much of the variance in organizational performance is attributed to the mediating role innovation in the market orientation-performance linkage [139]. Similarly, technology orientation and entrepreneurship orientation lead to the development of innovation by creating additional knowledge learning behaviours [123]. Firms that acquire and use their knowledge are able to create new solutions by exploiting their existing knowledge and exploring new knowledge to address customer needs that influences firm performance [57] [142]. As a result, firms with strategic orientation are able to display greater ability to innovate that allows them to respond more successfully to changes in the environment and develop skills that enable them to gain a competitive advantage, ultimately leading to improved performance [143].

Having a successful strategy and a clear strategic orientation paves the way for organizations to become increasingly creative and innovative, which in the end determines whether organizations will survive and thrive or whether they will deteriorate and die. Thus, the main purpose of this study was to investigate the mediating role played by innovation in the link between strategic orientation and organizational performance. The findings of this research revealed that the questionnaire used to measure the three variables demonstrated good qualities in terms of reliability and validity. The 
demographic profile of the respondents that participated in this study showed that the majority of the respondents were males, aged between 25 and less than 30 years old, have experience of 3-less than 6 years, and hold non-managerial positions.

In addition, the descriptive statistics showed the mean and standard deviation of each dimension and variable used in the questionnaire. The results showed that the respondents had positive attitudes towards all the variables used in this study. The results of conducting the path analysis using structural equation modelling showed that strategic orientation did not significantly affect organizational performance, but did have a significant effect on innovation. Furthermore, the results indicated that innovation did have a significant effect on organizational performance. Regarding the test for mediation, it was found that innovation did mediate the link between strategic orientation and organizational performance but only partially.

\section{Conclusion}

Although this study was based on existing literature, previous studies have been undertaken in different settings and contexts to the one adopted in this study. Therefore, this study contributes to the understanding of the importance of implementing a set of different strategic orientations that enable Jordanian telecommunication companies to develop innovative capabilities that in turn allow them to improve their performance, specifically non-financial performance. Most studies have focused on studying the effect of either strategic orientation or innovation on performance on their own. However, this study did not settle for that, rather it focused on studying whether innovation played a mediating role between strategic orientation and organizational performance.

\section{References}

[1] Abdallah, A., Obeidat, B. and Aqqad, N. (2014) The Impact of Supply Chain Management Practices on Supply Chain Performance in Jordan: The Moderating Effect of Competitive Intensity. International Business Research, 7, 13-27. http://dx.doi.org/10.5539/ibr.v7n3p13

[2] Masa'deh, R., Shannak, R., Obeidat, B., Almajali, D. and Dahalin, Z. (2010) Investigating a Causal Model of IT-Business Partnership and Competitive Advantage. Proceedings of the 14th IBIMA Conference on Global Business Transformation through Innovation and Knowledge Management: An Academic Perspective, Istanbul, 23-24 June 2010, 1250-1260.

[3] Zehir, C., Can, E. and Karaboga, T. (2015) Linking Entrepreneurial Orientation to Firm Performance: The Role of Differentiation Strategy and Innovation Performance. Procedia-Social and Behavioral Sciences, 210, 358-367. http://dx.doi.org/10.1016/j.sbspro.2015.11.381

[4] Altindag, E., Zehir, C. and Acar, A. Z. (2011) Strategic Orientations and Their Effects on Firm Performance in Turkish Family Owned Firms. Eurasian Business Review, 1, 18-36.

[5] Obeidat, B., Al-Suradi, M., Masa'deh, R. and Tarhini, A. (2016) The Impact of Knowledge Management on Innovation: An Empirical Study on Jordanian Consultancy Firms. Management Research Review, 39, 1214-1238. http://dx.doi.org/10.1108/mrr-09-2015-0214

[6] Shannak, R., Masa'deh, R., Al-Zu’bi, Z., Obeidat, B., Alshurideh, M. and Altamony, H. (2012) A Theoretical Perspective on the Relationship between Knowledge Management Systems, Customer Knowledge Management, and Firm Competitive Advantage. European 
Journal of Social Sciences, 32, 520-532.

[7] Hilman, H. and Kaliappen, N. (2014) Market Orientation Practices and Effects on Organizational Performance: Empirical Insight from Malaysian Hotel Industry. SAGE Open, 4, 1-8. http://dx.doi.org/10.1177/2158244014553590

[8] Masa'deh, R., Tarhini, A., Al-Dmour, R.H. and Obeidat, B.Y. (2015) Strategic IT-Business Alignment as Managers' Explorative and Exploitative Strategies. European Scientific Journal, 11, 437-457.

[9] Shannak, R. (2013) Key Issues in E-Banking Strengths and Weaknesses: The Case of Two Jordanian Banks. European Scientific Research, 9, 239-263.

[10] Theodosiou, M., Kehagias, J. and Katsikea, J. (2012) Strategic Orientations, Marketing Capabilities and Firm Performance: An Empirical Investigation in the Context of Frontline Managers in Service Organizations. Industrial Marketing Management, 41, 1058-1070. http://dx.doi.org/10.1016/j.indmarman.2012.01.001

[11] Sarker, S. and Palit, M. (2015) Strategic Orientation and Performance of Small and Medium Enterprises in Bangladesh. International Journal of Entrepreneurship and Small Business, 24, 572-586. http://dx.doi.org/10.1504/IJESB.2015.068643

[12] Al-Ansaari, Y., Bederr, H. and Chen, C. (2015) Strategic Orientation and Business Performance. Management Decision, 53, 2287-2302. http://dx.doi.org/10.1108/MD-01-2015-0034

[13] O’Regan, N. and Ghobadian, A. (2005) Innovation in SMEs: The Impact of Strategic Orientation and Environmental Perceptions. International Journal of Productivity and Performance Management, 54, 81-97. http://dx.doi.org/10.1108/17410400510576595

[14] Masa'deh, R. and Shannak, R. (2012) Intermediary Effects of Knowledge Management Strategy and Learning Orientation on Strategic Alignment and Firm Performance. Research Journal of International Studies, 24, 112-128.

[15] Thoumrungroje, A. and Racela, O. (2013) The Contingent Role of Customer Orientation and Entrepreneurial Orientation on Product Innovation and Performance. Journal of Strategic Marketing, 21, 140-159. http://dx.doi.org/10.1080/0965254X.2012.742129

[16] Lin, C.Y. and Chen, M.Y. (2007) Does Innovation Lead to Performance? An Empirical Study of SMEs in Taiwan. Management Research News, 30, 115-132. http://dx.doi.org/10.1108/01409170710722955

[17] Keskin, H. (2006) Market Orientation, Learning Orientation, and Innovation Capabilities in SMEs. European Journal of Innovation Management, 9, 396-417. http://dx.doi.org/10.1108/14601060610707849

[18] Inauen, M. and Schenker-Wicki, A. (2012) Fostering Radical Innovations with Open Innovation. European Journal of Innovation Management, 15, 212-231. http://dx.doi.org/10.1108/14601061211220986

[19] Masa'deh, R., Shannak, R., Maqableh, M. and Tarhini, A. (2016 A) The Impact of Knowledge Management on Job Performance in Higher Education: The Case of the University of Jordan. Journal of Enterprise Information Management, 29, 13-37.

[20] Lee, J.Y. (2011) Incremental Innovation and Radical Innovation: The Impacts of Human, Structural, Social, Relational Capital Elements. Unpublished PhD Thesis, Michigan State University, East Lansing.

[21] Baregheh, A., Rowley, J., Sambrook, S. and Davies, D. (2012) Food Sector SMEs and Innovation Types. British Food Journal, 114, 1640-1653. http://dx.doi.org/10.1108/00070701211273126 
[22] Obeidat, B., Masa'deh, R. and Abdallah, A. (2014) The Relationships among Human Resource Management Practices, Organizational Commitment, and Knowledge Management Processes: A Structural Equation Modeling Approach. International Journal of Business and Management, 9, 9-26. http://dx.doi.org/10.5539/ijbm.v9n3p9

[23] Valos, M.J. and Bednall, D.H. (2010) The Alignment of Market Research with Business Strategy and CRM. Journal of Strategic Marketing, 18, 187-199. http://dx.doi.org/10.1080/09652540903537022

[24] Gao, G., Zhou, K. and Yim, C. (2007) On What should Firms Focus in Transitional Economies? A Study of the Contingent Value of Strategic Orientations in China. International Journal of Research in Marketing, 24, 3-15. http://dx.doi.org/10.1016/j.ijresmar.2006.09.004

[25] Kumar, K., Boesso, G., Favotto, F. and Menini, A. (2012) Strategic Orientation, Innovation Patterns and Performances of SMEs and Large Companies. Journal of Small Business and Enterprise Development, 19, 132-145. http://dx.doi.org/10.1108/14626001211196442

[26] Merriam-Webster (2009) Online Dictionary. http://www.merriam-webster.com/dictionary/orientation

[27] Avci, U., Madanoglu, M. and Okumus, F. (2011) Strategic Orientation and Performance of Tourism Firms: Evidence from a Developing Country. Tourism Management, 32, 147-157. http://dx.doi.org/10.1016/j.tourman.2010.01.017

[28] Grawe, S.J., Chen, H. and Daugherty, P.J. (2009) The Relationship between Strategic Orientation, Service Innovation, and Performance. International Journal of Physical Distribution \& Logistics Management, 39, 282-300. http://dx.doi.org/10.1108/09600030910962249

[29] Balodi, K.C. (2014) Strategic Orientation and Organizational Forms: An Integrative Framework. European Business Review, 26, 188-203. http://dx.doi.org/10.1108/EBR-08-2013-0106

[30] Hakala, H. (2011) Strategic Orientations in Management Literature: Three Approaches to Understanding the Interaction between Market, Technology, Entrepreneurial and Learning Orientations. International Journal of Management Reviews, 13, 199-217. http://dx.doi.org/10.1111/j.1468-2370.2010.00292.x

[31] Masa'deh, R., Gharaibeh, A., Tarhini, A. and Obeidat, B. (2015) Knowledge Sharing Capability: A Literature Review. 4th Scientific \& Research Conference on New Trends in Business, Management and Social Sciences, Istanbul, 19-20 September 2015, 1-16.

[32] Shannak, R., Obeidat, B. and Masadeh, R. (2012) Culture and the Implementation Process of Strategic Decisions in Jordan. Journal of Management Research, 4, 257-281. http://dx.doi.org/10.5296/jmr.v4i4.2160

[33] Kohli, A.K. and Jaworski, B.J. (1990) Market Orientation: The Construct, Research Propositions, and Managerial Implications. Journal of Marketing, 54, 1-18.

http://dx.doi.org/10.2307/1251866

[34] Narver, J.C. and Slater, S.F. (1990) The Effect of a Market Orientation on Business Profitability. Journal of Marketing, 54, 20-35. http://dx.doi.org/10.2307/1251757

[35] Voss, G.B. and Voss, Z.G. (2000) Strategic Orientation and Firm Performance in an Artistic Environment. Journal of Marketing, 64, 67-83. http://dx.doi.org/10.1509/jmkg.64.1.67.17993

[36] Zhou, K.Z., Yim, C.K.B. and Tse, D.K. (2005) The Effects of Strategic Orientations on Technology and Market-Based Breakthrough Innovations. Journal of Marketing, 69, 42-60. http://dx.doi.org/10.1509/jmkg.69.2.42.60756

[37] Liao, S.H., Chang, W.J., Wu, C.C. and Katrichis, J.M. (2011) A Survey of Market Research 
(1995-2008). Industrial Marketing Management, 40, 301-310.

http://dx.doi.org/10.1016/j.indmarman.2010.09.003

[38] Mokhtar, S.S.M., Yusoff, R.Z. and Ahmad, A. (2014) Key Elements of Market Orientation on Malaysian SMEs Performance. International Journal of Business and Society, 15, 49-64.

[39] Ellis, P.D. (2006) Market Orientation and Performance: A Meta-Analysis and Cross National Comparisons. Journal of Management Studies, 43, 1089-1097. http://dx.doi.org/10.1111/j.1467-6486.2006.00630.x

[40] Kirca, A.H., Jayachandran, S. and Bearden, W.O. (2005) Market Orientation: A Meta-Analytic Review and Assessment of Its Antecedents and Impact on Performance. Journal of Marketing, 69, 24-41. http://dx.doi.org/10.1509/jmkg.69.2.24.60761

[41] Shapiro, B.P. (1988) What the Hell Is Market Oriented? Harvard Business Review, 66, 119125.

[42] Mahmoud, M.A., Blankson, C., Owusu-Frimpong, N., Nwankwo, S. and Trang, T.P. (2016) Market Orientation, Learning Orientation and Business Performance. International Journal of Bank Marketing, 34, 623-648. http://dx.doi.org/10.1108/IJBM-04-2015-0057

[43] Masa'deh, R.,Obeidat, B. and Tarhini, A. (2016) A Jordanian Empirical Study of the Associations among Transformational Leadership, Transactional Leadership, Knowledge Sharing, Job Performance, and Firm Performance: A Structural Equation Modelling Approach. Journal of Management Development, 35, 681-705. http://dx.doi.org/10.1108/JMD-09-2015-0134

[44] Chen, H.L. and Hsu, C.-H. (2013) Entrepreneurial Orientation and Firm Performance in Non-Profit Service Organizations: Contingent Effect of Market Orientation. The Service Industries Journal, 33, 445-466. http://dx.doi.org/10.1080/02642069.2011.622372

[45] Tsering, C. (2015) The Mediating Role of Entrepreneurial Orientation in the Market Orientation-Performance Relationship. Proceeding of the United States Association for Small Businesses and Entrepreneurship.

[46] Real, J.C., Roldan, J.L. and Leal, A. (2014) From Entrepreneurial Orientation and Learning Orientation to Business Performance: Analysing the Mediating Role of Organizational Learning and the Moderating Effects of Organizational Size. British Journal of Management, 25, 186-208. http://dx.doi.org/10.1111/j.1467-8551.2012.00848.x

[47] Dess, G.D., Pinkham, B.C. and Yang, H. (2011) Entrepreneurial Orientation: Assessing the Construct's Validity and Addressing Some of Its Implications for Research in the Areas of Family Business and Organizational Learning. Entrepreneurship Theory Practice, 35, 1077 1090. http://dx.doi.org/10.1111/j.1540-6520.2011.00480.x

[48] Gupta, V.K. and Gupta, A. (2015) Relationship between Entrepreneurial Orientation and Firm Performance in Large Organizations over Time. Journal of International Entrepreneurship, 13, 7-27. http://dx.doi.org/10.1007/s10843-014-0138-0

[49] Covin, J.G. and Slevin, D. (1989) Strategic Management of Small Firms in Hostile and Benign Environments. Strategic Management Journal, 10, 75-87. http://dx.doi.org/10.1002/smj.4250100107

[50] Covin, J.G. and Slevin, D. (1991) A Conceptual Model of Entrepreneurship as Firm Behavior. Entrepreneurship Theory Practice, 16, 7-25.

[51] Miller, D. (1983) The Correlates of Entrepreneurship in Three Types of Firms. Management Science, 29, 770-791. http://dx.doi.org/10.1287/mnsc.29.7.770

[52] Lumpkin, G.T. and Dess, G.G. (1996) Clarifying the Entrepreneurial Orientation Construct and Linking It to Performance. Academy of Management Review, 21, 135-172.

[53] Etemad, H. (2015) Entrepreneurial Orientation-Performance Relationship in the Interna- 
tional Context. Journal of International Entrepreneurship, 13, 1-6.

http://dx.doi.org/10.1007/s10843-015-0150-Z

[54] Altamony, H., Masa'deh, R., Alshurideh, M. and Obeidat, B. (2012) Information Systems for Competitive Advantage: Implementation of an Organisational Strategic Management Process. Proceedings of the 18th IBIMA Conference on Innovation and Sustainable Economic Competitive Advantage: From Regional Development to World Economic, Istanbul, 9-10 May 2012, 583-592.

[55] Masa'deh, R. (2013) The Impact of Information Technology Infrastructure Flexibility on Firm Performance: An Empirical Study of Jordanian Public Shareholding Firms. Jordan Journal of Business Administration, 9, 204-224. http://dx.doi.org/10.12816/0002054

[56] Shannak, R., Masa'deh, R., Obeidat, B. and Almajali, D. (2010) Information Technology Investments: A Literature Review. Proceedings of the 14th IBIMA Conference on Global Business Transformation through Innovation and Knowledge Management. An Academic Perspective, Istanbul, 23-24 June 2010, 1356-1368.

[57] Tsou, H.T., Chen, J.S. and Liao, W.H. (2014) Market and Technology Orientations for Service Delivery Innovation: The Link of Innovative Competence. Journal of Business \& Industrial Marketing, 29, 499-513. http://dx.doi.org/10.1108/JBIM-09-2011-0128

[58] Zhou, K.Z. and Li, C.B. (2010) How Strategic Orientations Influence the Building of Dynamic Capability in Emerging Economies. Journal of Business Research, 63, 224-231. http://dx.doi.org/10.1016/j.jbusres.2009.03.003

[59] Jeong, I., Pae, J.H. and Zhou, D. (2006) Antecedents and Consequences of the Strategic Orientations in New Product Development: The Case of Chinese Manufacturers. Industrial Marketing Management, 35, 348-358. http://dx.doi.org/10.1016/j.indmarman.2005.06.010

[60] Salojarvi, H., Ritala, P., Sainio, L.-M. and Saarenketo, S. (2015) Synergistic Effect of Technology and Customer Relationship Orientations: Consequences for Market Performance. Journal of Business \& Industrial Marketing, 30, 511-520. http://dx.doi.org/10.1108/JBIM-07-2012-0120

[61] Gungor, D.O. and Gozlu, S. (2012) Influencing Factors of Innovation for Turkish Companies. International Journal of Quality and Service Sciences, 4, 374-386.

http://dx.doi.org/10.1108/17566691211288359

[62] Barney, J.B. (2001) Resource-Based Theories of Competitive Advantage: A Ten-Year Retrospective on the Resource-Based View. Journal of Management, 27, 643-650. http://dx.doi.org/10.1177/014920630102700602

[63] Hajir, J.A., Obeidat, B.Y., Al-dalahmeh, M.A. and Masa'deh, R. (2015) The Role of Knowledge Management Infrastructure in Enhancing Innovation at Mobile Telecommunication Companies in Jordan. European Journal of Social Sciences, 50, 313-330.

[64] Mothe, C. and Thi, T.U.N. (2010) The Link between Non-Technological Innovations and Technological Innovation. European Journal of Innovation Management, 13, 313-333. http://dx.doi.org/10.1108/14601061011060148

[65] Kanaan, R., Masa'deh, R. and Gharaibeh, A. (2013) The Impact of Knowledge Sharing Enablers on Knowledge Sharing Capability: An Empirical Study on Jordanian Telecommunication Firms. European Scientific Journal, 9, 237-258.

[66] Kateb, G.A., Swies, R. and Maqableh, M. (2014) An Investigation on the Critical Factors of Information System Implementation in Jordanian Information Technology Companies. European Journal of Business and Management, 7, 11-28.

[67] Massa, S. and Testa, S. (2004) Innovation or Imitation? Benchmarking. An International Journal, 11, 610-620. 
[68] Alavi, M. and Leidner, D.E. (2001) Knowledge Management and Knowledge Management Systems: Conceptual Foundations and Research Issues. MIS Quarterly, 25, 107-136. http://dx.doi.org/10.2307/3250961

[69] Albino, V., Garavelli, A.C. and Schiuma, G. (2001) A Metric for Measuring Knowledge Codification in Organization Learning. Technovation, 21, 413-422. http://dx.doi.org/10.1016/S0166-4972(00)00058-4

[70] Van Wagenberg, T.M.A. and Wubben, E. (2005) Innovation Process and Innovativeness of Facility Management Organizations. Facilities, 23, 103-118. http://dx.doi.org/10.1108/02632770510578485

[71] O’Sullivan, D. and Dooley, L. (2008) Applying Innovation. Sage Publications Inc., Thousand Oaks.

[72] Garcia, R. and Calantone, R. (2002) A Critical Look at Technological Innovation Typology and Innovativeness Terminology: A Literature Review. Journal of Product Innovation Management, 19, 110-132. http://dx.doi.org/10.1016/S0737-6782(01)00132-1

[73] Oke, A., Burke, G. and Myers, A. (2007) Innovation Types and Performance in Growing UK SMEs. International Journal of Operations \& Production Management, 27, 735-753. http://dx.doi.org/10.1108/01443570710756974

[74] Alexander, L. and Van Knippenberg, D. (2014) Teams in Pursuit of Radical Innovation: A Goal Orientation Perspective. Academy of Management Review, 39, 423-438. http://dx.doi.org/10.5465/amr.2012.0044

[75] Robbins, P. and O’Gorman, C. (2015) Innovating the Innovation Process: An Organisational Experiment in Global Pharma Pursuing Radical Innovation. R\&D Management, 45, 76-93. http://dx.doi.org/10.1111/radm.12054

[76] O’Neill, H.M., Pouder, R.W. and Buchholtz, A.K. (1998) Patterns in the Diffusion of Strategies across Organisations; Insights from the Innovation Diffusion Literature. Academy of Management Review, 23, 98-114.

[77] Johnson, J.D. (2001) Success in Innovation Implementation. Journal of Communication Management, 5, 341-359. http://dx.doi.org/10.1108/13632540110806875

[78] Sorensen, J.B. And Stuart, T.E. (2000) Aging, Obsolescence and Organizational Innovation. Administrative Science Quarterly, 45, 81-112. http://dx.doi.org/10.2307/2666980

[79] Engen, M. and Holen, I.E. (2014) Radical versus Incremental Innovation: The Importance of Key Competences in Service Firms. Technology Innovation Management Review, 4, 15 25.

[80] Ordanini, A. and Parasuraman, A. (2011) Service Innovation Viewed Through a ServiceDominant Logic Lens: A Conceptual Framework and Empirical Analysis. Journal of Service Research, 14, 3-23. http://dx.doi.org/10.1177/1094670510385332

[81] Damanpour, F. (2009) Combinative Effects of Innovation Types and Organizational Performance: A Longitudinal Study of Service Organizations. Journal of Management Studies, 46, 650-675. http://dx.doi.org/10.1111/j.1467-6486.2008.00814.x

[82] Fabrizio, K.R. and Thomas, L.G. (2012) The Impact of Local Demand on Innovation in a Global Industry. Strategic Management Journal, 33, 42-64.

http://dx.doi.org/10.1002/smj.942

[83] Sternberg, R. and Arndt, O. (2001) The Firm or The Region: What Determines The Innovation Behaviour of European Firms? Economic Geography, 77, 364-382.

http://dx.doi.org/10.2307/3594106

[84] Roper, S. and Love, J.H. (2002) Innovation and Export Performance: Evidence from UK and German Manufacturing Plants. Research Policy, 31, 1087-1102. 
http://dx.doi.org/10.1016/S0048-7333(01)00175-5

[85] Wang, C.L., Hult, G.T.M., Kitchen Jr., D.J. and Ahmad, P.K. (2009) Knowledge Management Orientation, Market Orientation, and Firm Performance: An Integration and Empirical Examination. Journal of Strategic Marketing, 17, 147-170.

http://dx.doi.org/10.1080/09652540902879326

[86] Wang, D. and Chen, S. (2013) Does Intellectual Capital Matter? High-Performance Work Systems and Bilateral Innovative Capabilities. International Journal of Manpower, 34, 861879. http://dx.doi.org/10.1108/IJM-07-2013-0167

[87] Lefebvre, V.M., De Steur, H. and Gellynck, X. (2015) External Sources for Innovation in Food SMEs. British Food Journal, 117, 412-430. http://dx.doi.org/10.1108/BFJ-09-2013-0276

[88] Bakovic, T., Lazibat, T. And Sutic, I. (2013) Radical Innovation Culture in Croatian Manufacturing Industry. Journal of Enterprising Communities. People and Places in the Global Economy, 7, 74-80. http://dx.doi.org/10.1108/17506201311315626

[89] Kim, C.W. and Mauborgne, R. (2005) Blue Ocean Strategy: From Theory to Practice. California Management Review, 47, 105-1021. http://dx.doi.org/10.2307/41166308

[90] Jansen, J.J., Bosch, F.A. and Volberda, H.W. (2006) Exploratory Innovation, Exploitative Innovation, and Performance: Effects of Organizational Antecedents and Environmental Moderators. Management Science, 52, 1661-1674. http://dx.doi.org/10.1287/mnsc.1060.0576

[91] Taylor, A. and Greve, H.R. (2006) Superman or the Fantastic Four? Knowledge Combination and Experience in Innovative Teams. Academy of Management Journal, 49, 723-740. http://dx.doi.org/10.5465/AMJ.2006.22083029

[92] Subramaniam, M. and Youndt, M.A. (2005) The Influence of Intellectual Capital on the Types of Innovative Capabilities. Academy of Management Journal, 48, 450-463. http://dx.doi.org/10.5465/AMJ.2005.17407911

[93] Stanley, K. (2012) Antecedents of Radical Innovation: Antecedents and Outcomes of Radical Innovation. Unpublished PhD Thesis, Alliant International University, San Diego.

[94] Norman, D.A. and Verganti, R. (2012) Incremental and Radical Innovation: Design Research versus Technology and Meaning Change.

http://jnd.org/dn.mss/Norman\%20\%26\%20Verganti.\%20Design\%20Research\%20\%26\%20I nnovation-18\%20Mar\%202012.pdf

[95] O’Connor, G.C. and Ayers, A. (2005) Building a Radical Innovation Competency. Research-Technology Management, 23-33.

[96] O’Connor, G.C. and DeMartino, R. (2006) Organizing for Radical Innovation: An Exploratory Study of the Structural Aspects of RI Management Systems in Large Established Firms. Journal of Product Innovation Management, 23, 475-497. http://dx.doi.org/10.1111/j.1540-5885.2006.00219.x

[97] Otero-Neira, C., Lindman, M.T. and Fernández, M.J. (2009) Innovation and Performance in SME Furniture Industries. Marketing Intelligence \& Planning, 27, 216-232. http://dx.doi.org/10.1108/02634500910944995

[98] Golder, P.S., Shacham, R. and Mitra, D. (2009) Innovations Origins: When, by Whom, and How Are Radical Innovations Developed. Marketing Science, 28, 166-179. http://dx.doi.org/10.1287/mksc.1080.0384

[99] Obeidat, B., El-Rimawi, S., Masa'deh, R., Maqableh, M. and Al-Jarrah, I. (2013) Evaluating the Profitability of the Islamic Banks in Jordan. European Journal of Economics, Finance and Administrative Sciences, 56, 27-36. 
[100] Tseng, S.M. and Lee, P.S. (2014) The Effect of Knowledge Management Capability and Dynamic Capability on Organizational Performance. Journal of Enterprise Information Management, 27, 158-179. http://dx.doi.org/10.1108/JEIM-05-2012-0025

[101] Al-Dmour, R., Obeidat, B., Masa'deh, R. and Almajali, D. (2015) The Practice of HRIS Applications in Business Organizations in Jordan: An Empirical Study. Proceedings of the 4th Scientific \& Research Conference on New Trends in Business, Management and Social Sciences, Istanbul, 19-20 September 2015, 53-74.

[102] Masa'deh, R., Obeidat, B., Zyod, D. and Gharaibeh, A. (2015) The Associations among Transformational Leadership, Transactional Leadership, Knowledge Sharing, Job Performance, and Firm Performance: A Theoretical Model. Journal of Social Sciences, 4, 848-866.

[103] Wheelen, T.L. and Hunger, J.D. (2015) Strategic Management and Business Policy. 14th Edition, Pearson Education Inc., New York.

[104] Robbins, S.P. and Coulter, M. (2007) Management. 9th Edition, Prentice-Hall, London.

[105] Cho, J. and Dansereau, F. (2010) Are Transformational Leaders Fair? A Multi-Level Study of Transformational Leadership, Justice Perceptions, and Organizational Citizenship Behaviors. The Leadership Quarterly, 21, 409-421. http://dx.doi.org/10.1016/j.leaqua.2010.03.006

[106] Tomal, D.R. and Jones, K.J. (2015) A Comparison of Core Competencies of Women and Men Leaders in the Manufacturing Industry. The Coastal Business Journal, 14, 13-25.

[107] Richard, P.J., Devinney, T.M., Yip, G.S. and Johnson, G. (2009) Measuring Organizational Performance: Towards Methodological Best Practice. Journal of Management, 35, 718-804. http://dx.doi.org/10.1177/0149206308330560

[108] Hamdam, H., Pakdel, A. and Soheili, S. (2012) The Study of Board's Remuneration and Its Relationship with Accounting Indicators for Firm's Performance Evaluation (Evidence from Tehran Stock Exchange). Australian Journal of Basic \& Applied Sciences, 6, 403-408.

[109] Falshaw, J.R., Glaister, K.W. and Tatoglu, E. (2006) Evidence on Formal Strategic Planning and Company Performance. Management Decision, 44, 9-30. http://dx.doi.org/10.1108/00251740610641436

[110] Garg, R.K. and Ma, J. (2005) Benchmarking Culture and Performance in Chinese Organizations. Benchmarking: An International Journal, 12, 260-274. http://dx.doi.org/10.1108/14635770510600375

[111] Shah, S. and Dubey, S. (2013) Market Orientation and Organizational Performance of Financial Institutions in United Arab Emirates. Journal of Management \& Public Policy, 4, 17-26.

[112] Wang, Y., Bhanugopan, R. and Lockhart, P. (2015) Examining the Quantitative Determinants of Organizational Performance: Evidence from China. Measuring Business Excellence, 19, 23-41. http://dx.doi.org/10.1108/MBE-05-2014-0014

[113] Panda, D.K. (2014) Managerial Networks and Strategic Orientation in SMEs. Journal of Strategy and Management, 7, 376-397. http://dx.doi.org/10.1108/JSMA-12-2013-0071

[114] Hernaus, T., Bach, M. and Vuksic, V. (2012) Influence of Strategic Approach to BPM on Financial and Non-Financial Performance. Baltic Journal of Management, 7, 376-396. http://dx.doi.org/10.1108/17465261211272148

[115] Sekaran, U. and Bougie, R. (2013) Research Methods for Business. 6th Edition, John Wiley \& Sons Ltd., Hoboken.

[116] Pallant, J. (2005) SPSS Survival Manual: A Step by Step Guide to Data Analysis Using SPSS for Windows. Version 12, 2nd Edition, Open University Press, Maidenhead.

[117] Bagozzi, R.P. and Yi, Y. (1988) On the Evaluation of Structural Equation Models. Journal of 
the Academy of Marketing Science, 16, 74-94. http://dx.doi.org/10.1007/BF02723327

[118] Hair, J., Black, W., Babin, B., Anderson, R. and Tatham, R. (2006) Multivariate Data Analysis. 6th Edition, Pearson Prentice Hall, Upper Saddle River.

[119] Creswell, J.W. (2009) Research Design: Qualitative, Quantitative, and Mixed Methods Approaches. 3rd Edition, Sage Publications Inc., Los Angeles.

[120] Fronell, C. and Larcker, D. (1981) Evaluating Structural Equation Models with Unobservable Variables and Measurement Error. Journal of Marketing Research, 18, 39-50. http://dx.doi.org/10.2307/3151312

[121] Altuntas, G., Semercioz, F. and Eregez, H. (2013) Linking Strategic and Market Orientations to Organizational Performance: The Role of Innovation in Private Healthcare Organizations. Procedia-Social and Behavioral Sciences, 99, 413-419. http://dx.doi.org/10.1016/j.sbspro.2013.10.509

[122] Manu, F.A. and Sriram A.V. (1996) Innovation Marketing Strategy Environment and Performance. Journal of Business Research, 35, 79-91. http://dx.doi.org/10.1016/0148-2963(95)00056-9

[123] Noble, C.H., Sinha, R.K. and Kumar, A. (2002) Market Orientation and Alternative Strategic Orientations: A Longitudinal Assessment of Performance Implications. Journal of Business Research, 66, 25-39.

[124] Eris, E.D., Neczan, O. and Ozmen, T. (2012) The Effect of Market Orientation, Learning Orientation and Innovativeness on Firm Performance: A Research from Turkish Logistics Sector. International Journal of Business and Economic Sciences Applied Research, 5, 77 108.

[125] Franczak, J., Weinzimmer, L. and Michel, E. (2009) An Empirical Examination of Strategic Orientation and SME Performance. Small Business Institute National Proceedings, 33, 6877.

[126] Hult, G.T.M., Ketchen, D.J. and Nichols, E.L. (2003) Organizational Learning as a Strategic Resource in Supply Management. Journal of Operations Management, 21, 541-556. http://dx.doi.org/10.1016/j.jom.2003.02.001

[127] Olson, E.M., Slater, S.F. and Hult, G.T.M. (2005) The Performance Implications of Fit among Business Strategy, Marketing Organization Structure, and Strategic Behavior. Journal of Marketing, 69, 49-65. http://dx.doi.org/10.1509/jmkg.69.3.49.66362

[128] Aghajari, N. and Senin, A. (2014) Strategic Orientation and Dual Innovative Operation Strategies. Asia-Pacific Journal of Business Administration, 6, 127-147. http://dx.doi.org/10.1108/APJBA-07-2013-0075

[129] Arnold, T.J., Fang, E. and Palmatier, R.W. (2011) The Effects of Customer Acquisition and Retention Orientations on a Firm's Radical and Incremental Innovation Performance. Journal of the Academy of Marketing Science, 39, 234-251. http://dx.doi.org/10.1007/s11747-010-0203-8

[130] Freitas, I.M.B., Fontana, R. and Adams, P. (2013) Strategic Orientations, Marketing Capabilities and Innovation: An Empirical Investigation. 35th DRUID Celebration Conference, Barcelona, 17-19 June 2013.

[131] Sorescu, A.B., Chandy, R.K. and Prabhu, J.C. (2003) Sources and Financial Consequences of Radical Innovation: Insights from Pharmaceuticals. Journal of Marketing, 67, 82-101. http://dx.doi.org/10.1509/jmkg.67.4.82.18687

[132] Yalcinkaya, G., Calantone, R.J. and Griffith, D.A. (2007) An Examination of Exploration and Exploitation Capabilities: Implications for Product Innovation and Market Performance. Journal of International Marketing, 15, 63-93. http://dx.doi.org/10.1509/jimk.15.4.63 
[133] Huang, C.J. and Liu, C.J. (2005) Exploration for the Relationship between Innovation, IT and Performance. Journal of Intellectual Capital, 6, 237-252. http://dx.doi.org/10.1108/14691930510592825

[134] Jiménez-Jiménez, D. and Sanz-Valle, R. (2011) Innovation, Organizational Learning, and Performance. Journal of Business Research, 64, 408-417. http://dx.doi.org/10.1016/j.jbusres.2010.09.010

[135] McEvily, S.K., Eisenhardt, K.M.M. and Prescott, J.E. (2004) The Global Acquisition, Leverage, and Protection of Technological Competencies. Strategic Management Journal, 25, 713-722. http://dx.doi.org/10.1002/smj.425

[136] Salim, I.M. and Sulaiman, M. (2011) Organizational Learning, Innovation and Performance: A Study of Malaysian Small and Medium Sized Enterprises. International Journal of Business and Management, 6, 118-125. http://dx.doi.org/10.5539/ijbm.v6n12p118

[137] Ul Hassan, M., Shaukat, S., Nawaz, M.S. and Naz, S. (2013) Effects of Innovation Types on Firm Performance: An Empirical Study on Pakistan's Manufacturing Sector. Pakistan Journal of Commerce and Social Sciences, 7, 243-262.

[138] Varis, M. and Littunen, H. (2010) Types of Innovation, Sources of Information and Performance in Entrepreneurial SMEs. European Journal of Innovation Management, 13, 128 154. http://dx.doi.org/10.1108/14601061011040221

[139] Agarwal, S., Erramilli, K.M. and Dev, C.D. (2003) Market Orientation and Performance in Service Firms: Role of Innovation. Journal of Services Marketing, 17, 68-82.

http://dx.doi.org/10.1108/08876040310461282

[140] Han, J.K., Kim, N. and Srivastava, R. (1998) Market Orientation and Organizational Performance: Is Innovation a Missing Link? Journal of Marketing, 62, 30-45. http://dx.doi.org/10.2307/1252285

[141] Zhao, X., Lynch Jr., J.G. and Chen, Q. (2010) Reconsidering Baron and Kenny: Myths and Truths about Mediation Analysis. Journal of Consumer Research, 37, 197-206. http://dx.doi.org/10.1086/651257

[142] Yu, X., Nguyen, B. and Chen, Y. (2016) Internet of Things Capability and Alliance. Internet Research, 26, 402-434. http://dx.doi.org/10.1108/IntR-10-2014-0265

[143] Hult, G.T.M., Hurley, R.F. and Knight, G.A. (2004) Innovativeness: Its Antecedents and Impact on Business Performance. Industrial Marketing Management, 33, 429-438. http://dx.doi.org/10.1016/j.indmarman.2003.08.015 
Submit or recommend next manuscript to SCIRP and we will provide best service for you:

Accepting pre-submission inquiries through Email, Facebook, LinkedIn, Twitter, etc. A wide selection of journals (inclusive of 9 subjects, more than 200 journals)

Providing 24-hour high-quality service

User-friendly online submission system

Fair and swift peer-review system

Efficient typesetting and proofreading procedure

Display of the result of downloads and visits, as well as the number of cited articles

Maximum dissemination of your research work

Submit your manuscript at: http://papersubmission.scirp.org/

Or contact ijcns@scirp.org 